\title{
Trophic connections of the brown marmorated stink bug Halyomorpha halys Stål in the conditions of the invasive area on the Black Sea coast of the Caucasus
}

\author{
Vilena Zakharchenko ${ }^{1}$, Natalia Karpun ${ }^{1, *}$, and Boris Borisov ${ }^{2}$ \\ ${ }^{1}$ Russian Research Institute of Floriculture and Subtropical Crops, Yana Fabritsiusa Street, 2/28, \\ Sochi, 354002, Russia \\ 2 "AgroBioTechnology" LLC (Production and research company), Kronshtadtskiy Blvd, 7-4, \\ Moscow, 125212, Russia
}

\begin{abstract}
Brown marmorated stink bug Halyomorpha halys (Stål, 1855) is a highly aggressive crop pest that has appeared in Russia since 2014. Under the conditions of a new invasive species area, it is important to study the characteristics of the pest biology, including the study of the range of trophic plants. The studies were carried out in the zone of humid subtropics of the Black Sea coast of the Caucasus in 2014-2019. The study of trophic connections was carried out in the course of regular surveys of the region's phytocenoses, including agrocenoses, landscape gardening and forest stands. During the observation period, the number of fodder plants of the brown marmorated stink bug was 107 species from 48 botanical families. The most diverse fodder plants of the Fabaceae, Rosaceae, Rutaceae, Sapindaceae and Solanaceae families. Among the food plants of H. halys, conifers are noted. It was Metasequoia glyptostroboides $\mathrm{Hu} \&$ W.C. Cheng and Taxodium mucronatum Ten. Migration ways of brown marmorated stink bug from forest plantations to agrocenoses, gardens and city parks have been established. Such movements allows the pest to eat variably and to wait for adverse conditions.
\end{abstract}

\section{Introduction}

Brown marmorated stink bug Halyomorpha halys (Stål, 1855) is one of the most famous and harmful invasive crop pests in the world. [1-4]. Even several individuals of the bug, being in favorable conditions for them, can damage many fruits. Due to polyphagy and two to three generations during the year, the pest is able to quickly increase the population to the level of outbreaks, causing significant economic damage $[4,5]$.

${ }^{*}$ Corresponding author: $\underline{\text { nkolem } @ \text { mail.ru }}$ 
Since 1996, the invasive area of $H$. halys has been expanding rapidly [3, 4]. In Russia, the pest was first recorded in 2014 in Sochi [6]. Subsequently, it spread throughout the Black Sea coast of the Caucasus, in the Crimea, in the plains of the Krasnodar and Stavropol Regions, it was singularly observed in the Rostov Region. Already in 2016, a brown marmorated stink bug led to economically significant losses of various crops in the Republic of Abkhazia [6].

It is known that brown marmorated stink bug can damage about 300 species of plants, including fruit, vegetables, nuts, crops, and also decorative and forest species [1,7-13]. The nymphs and adults of $H$. halys are able to easily move between fodder plants, choosing the crops most suitable for feeding in a given period [3,4].

To assess the possibility of adapting a new invasive pest species in the region and building an effective protection system with it, it is important to have a clear understanding of the fodder plants spectrum, the presence of possible migrations from one crop to another, and the timing of these migrations. Therefore, the purpose of this research was to study the trophic connections of the brown marmorated stink bug in the new part of its invasive range on the Black Sea coast of the Caucasus.

\section{Materials and methods}

Studies were conducted from 2014 to 2019 in the humid subtropics of the Black Sea coast of the Caucasus. Identification of individuals of the brown marmorated stink bug was carried out by weekly (from April to October) routine surveys of agrocenoses, ornamental and forest stands in various areas of Sochi (Adler, Khostinsky, Central, Lazarevsky), as well as monthly surveys in the territory of Abkhazia. The identification of the pest was carried out according to morphological characteristics [13]. Definition of fodder plants was carried out according to the identifiers of vascular plants and botanical Internet resources.

\section{Results and discussion}

The first detection of brown marmorated stink bug in the region of humid subtropics was in 2014. The pest was found by the assistant professor of the Russian State Agrarian University I.M. Mityushev on Rosa sp. and Pittosporum sp. in two parks in Sochi [6].

In the autumn of 2015, a sharp increase in the number of $H$. halys was observed in the region (before leaving for overwintering), but during the growing season in the agrocenoses or ornamental plantings, the pest was not noted in any noticeable amounts.

During the growing season of 2016, the pest was identified by us on 18 feed plants (Fig. 1), including on Malus domestica Borkh., Pyrus communis L., Prunus persica (L.) Batsch, Citrus reticulata var. unshiu Tan., Citrus limon (L.) Osbeck, Ficus carica L., Vitis vinifera L., some vegetable and ornamental crops. The bug was fed on the juicy parts of plants. On fruit and vegetable crops, the pest fed mainly on fruits, and on ornamental ones, on young shoots and leaves.

In $2017, H$. halys was noted by us on plants of 18 species belonging to 12 families (Fig. 1). For the first time in the research region, brown marmorated stink bug was detected on the leaves and fruits of Diospyros kaki Thunb., Corylus avellana L., Actinidia deliciosa (A.A. Chev.) C.F. Liang et A.R. Ferguson, Citrus sinensis (L.) Osbeck, Citrus $\times$ meyeri Yu.Tanaka, Citrus paradisi Macfad, Ziziphus jujuba Mill., Prunus laurocerasus L., Morus alba L., Robinia pseudoacacia L., Hippophaë rhamnoides L., on the fruits of Prunus domestica L. и Lantana camara L., on the leaves of Chrysanthemum sp., Rhododendron sp., Gleditsia triacanthos L., Fraxinus excelsior L. и Prunus avium L. Special attention 
should be paid to the finding of adult second generation bugs in the autumn on the needles and cones of Metasequoia glyptostroboides Hu \& W.C.Cheng.

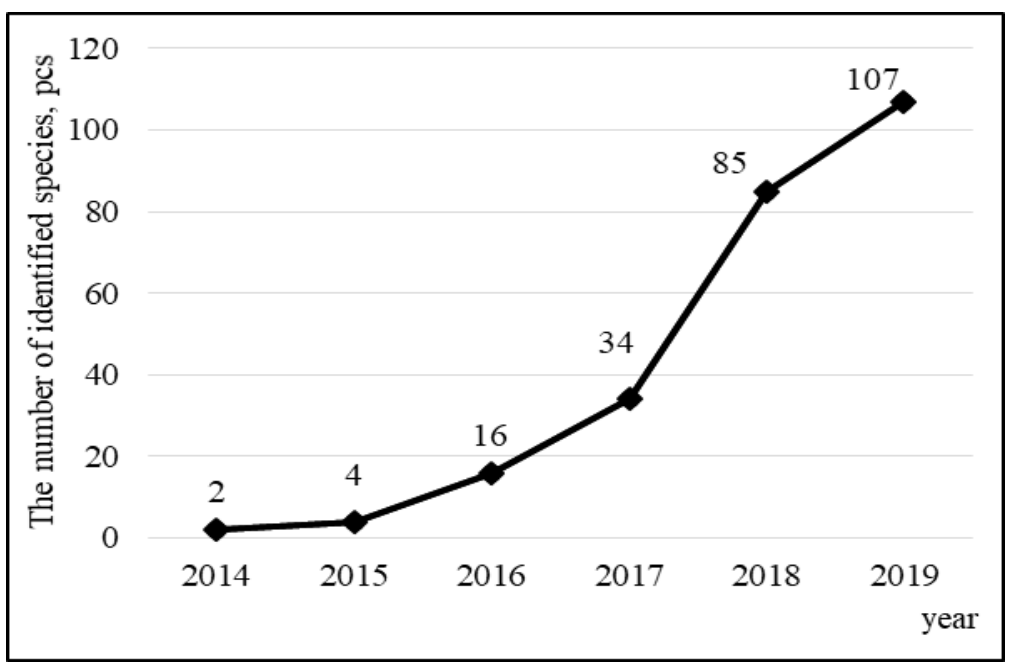

Fig.1. The dynamics of revealing brown marmorated stink bug fodder plants, Sochi, 2014-2019

In 2018, when conducting surveys of the region's phytocenoses, special attention was paid to forest stands adjacent to the city line or to villages. According to the results of observations this year, the number of plants on which $H$. halys were observed increased by another 34 species. Thus, the total number of fodder plants of the brown marmorated stink bug was 85 species belonging to 37 families.

During 2019, the pest expanded its assortment of feed species. So, by the end of the growing season of 2019, their number was 107 species from 48 families. This year, another coniferous plant, Taxodium mucronatum Ten., was identified as fodder for the bug. The needles and cones of Taxodium were marked by the feeding of a large number of $H$. halys adults in September - October. In general, conifers are not characteristic of the diet of a brown-marble bug, although there is information about the nutrition of the bug on Pinus strobus L., P. wallichiana A.B. Jacks., Picea glauca (Moench) Voss, P. abies (L.) H. Karst., Juniperus virginiana L., J. chinensis L. and Cryptomeria japonica D. Don [11, 14]. Both Metasequoia and Taxodium are coniferous trees belonging to the Cupressaceae family. Perhaps they attracted the bug by the features of the needles, which is characterized by softness and low content of essential oils.

When analyzing trophic connections, it was found that the families Fabaceae and Rosaceae are distinguished by the greatest variety of fodder plants species (Fig. 2). In which 12 species of fodder plants of a brown marmorated stink bug were identified. Five species of fodder plants each belong to the families Rutaceae, Sapindaceae, and Solanaceae. The remaining families include 1-4 species, from which it can be concluded that the circle of trophic connections of $H$. halys in the region will further expand. 


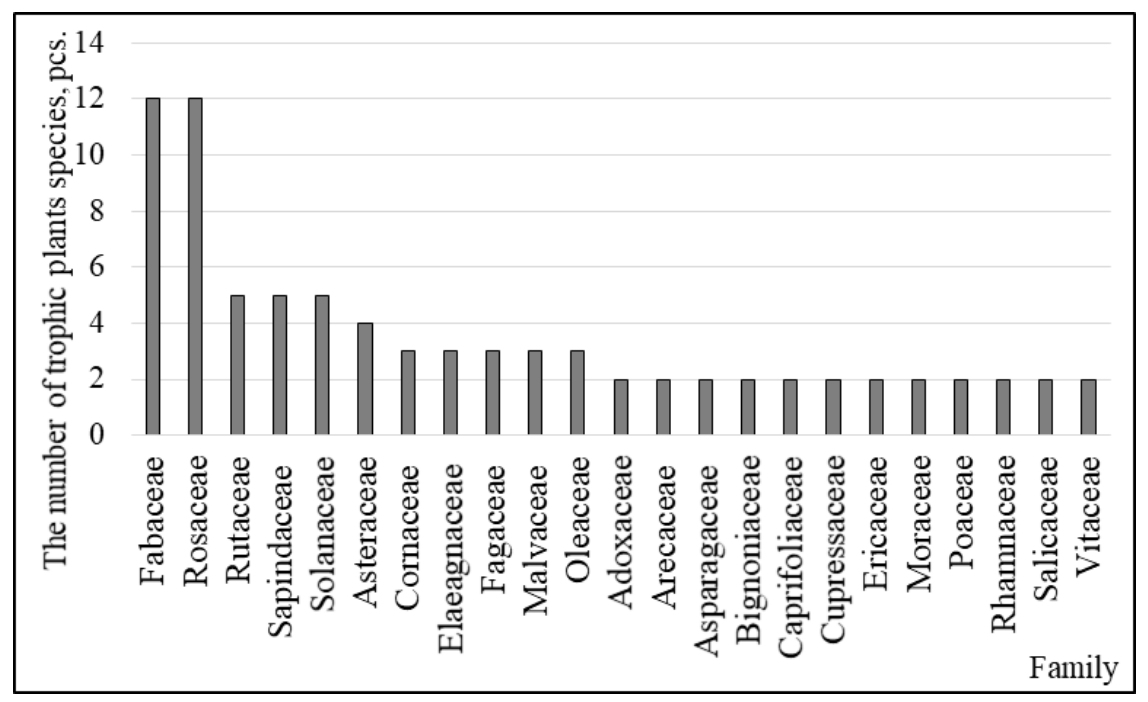

Fig.2. Distribution of brown marmorated stink bug fodder plants species by botanical families, Sochi, 2014-2019

In the process of conducting phytocenosis surveys, the fact of brown marmorated stink bug migration from forest stands to household plots, gardens and city parks was established, which allows the pest to diversify its diet, but at the same time complicating the organization of the plant protection system from it. This phenomenon was also observed in other parts of the invasive space, which is confirmed by published data [4, 15]. In this regard, the establishment of patterns of change in fodder plants at different times of the growing season is an important task.

In the spring, in the second half of May, adults leave overwintering places and begin additional nutrition on woody plants widely found in the region - Catalpa speciosa (Warder ex Barney) Warder ex Engelm., Paulownia tomentosa Steud., Prunus laurocerasus L., Morus alba L., Corylus avellana L., Eriobotrya japonica (Thunb.) Lindl., Prunus persica (L.) Batsch и Prunus cerasifera Ehrh. These cultures are found not only in agrocenoses and ornamental plantings, but also along roads and in the forests of the Sochi National Park and the Caucasian Biosphere Reserve. Nymphs of the first generation can subsequently continue feeding on these plants or fall from their crowns and creep out in search of other food sources, for example, Rubus caucasicus L., Rosa spp., Rumex crispus L., Solanum dulcamara L. and others.

Beginning in the second half of June, the first-generation adults move to planting vegetables, where they continue to develop until mid-August. The second generation of the bug prefers subtropical crops - citrus crops, persimmons, as well as grapes and corn. In August - September, the bug also returns to Paulownia and Catalpa.

If $H$. halys occurs on plantations of hazelnuts massively in late May - early June, then on Corylus avellana (L.) H.Karst. in forest stands at this time of year, the pest is extremely rare, and in September the number of bugs on it increases very much. Also in the autumn months, one can observe clusters of adult bugs on the leaves of forest species - beech (Fagus orientalis Lipsky), linden (Tilia caucasica Rupr.), ash (Fraxinus excelsior L.). 


\section{Conclusion}

Thus, the number of fodder plants $H$. halys identified in the zone of humid subtropics of the Black Sea coast of the Caucasus amounted to 107 species from 48 botanical families. Most plant species are crops (fruit, subtropical, vegetable, and grain) or ornamental introduced trees and shrubs used in landscaping. The greatest species diversity of fodder plants was noted in the Fabaceae, Rosaceae, Rutaceae, Sapindaceae, and Solanaceae families. Among coniferous fodder plants, Metasequoia glyptostroboides and Taxodium mucronatum are noted.

A migration of a brown marmorated stink bug during the growing season from one fodder plants to another, including from natural plantings to agrocenoses and vice versa, was noted.

\section{References}

1. D.-H. Lee, B.D. Short, S.V. Joseph, J.C. Bergh, T.C. Leskey, Environ. Entomol., 42(4), 627-641 (2013) https://doi.org/10.1603/EN13006

2. K.B. Rice, C.J. Bergh, E.J. Bergmann, D.J. Biddinger, C. Dieckhoff, G. Dively, H. Fraser, T. Gariepy, G. Hamilton, T. Haye, A. Herbert, K. Hoelmer, C.R. Hooks, A. Jones, G. Krawczyk, T. Kuhar, H. Martinson, W. Mitchell, A.L. Nielsen, D.G. Pfeiffer, M.J. Raupp, C. Rodriguez-Saona, P. Shearer, P. Shrewsbury, P. Dilip Venugopal, J. Whalen, N.G. Wiman, T. C. Leskey, J.F. Tooker, Journal Of Integrated Pest Management, 5(3), 1-12 (2014) https://doi.org/10.1603/IPM14002

3. T. Haye, T. Gariepy, K. Hoelmer, J.-P. Rossi, J.-C. Streito, X. Tassus, N. Desneux, J Pest Sci., 88, 665-673 (2015) https://doi.org/10.1007/s10340-015-0670-2

4. L. Maistrello, G. Vaccari, S. Caruso, E. Costi, S. Bortolini, L. Macavei, G. Foca, A. Ulrici, P. P. Bortolotti, R. Nannini, L. Casoli, M. Fornaciari, G.L. Mazzoli, P. Dioli, J Pest Sci, 90, 1231-1244 (2017) https://doi.org/10.1007/s10340-017-0896-2

5. D.L. Musolin, M.Yu. Dolgovskaya, V.Ye. Protsenko, N.N. Karpun, S.Ya. Reznik, A.Kh. Saulich, J Pest Sci 92, 621-631 (2019) https://doi.org/10.1007/s10340-019-01080-1

6. D.L. Musolin, A. Konjević, N.N. Karpun, V.Ye. Protsenko, L.Ya. Ayba, A.Kh. Saulich, Arthropod-Plant Interactions, 12, 517-529 (2018) https://doi.org/10.1007/s11829-017-9583-8

7. T.C. Leskey, G.C. Hamilton, A.L. Nielsen, D.F. Polk, C. Rodriguez-Saona, J.C. Bergh, D.A. Herbert, T.P. Kuhar, D. Pfeiffer, G.P. Dively, C.R.R. Hooks, M.J. Raupp, P.M. Shrewsbury, G. Krawczyk, P.W. Shearer, J. Whalen, C. Koplinka-Loehr, E. Myers, D. Inkley, K.A. Hoelmer, D.-H. Lee, S.E. Wright, Outlooks on Pest Management, 23(5), 218-226 (2012) https://doi.org/10.1564/23oct07

8. T.D. Gariepy, H. Fraser, C.D. Scott-Dupree, Can. Entomol., 146(5), 1-4 (2014) https://doi.org/10.4039/tce.2014.4

9. A.L. Acebes-Doria, T.C. Leskey, J.C. Bergh, Entomologia Experimentalis et Applicata, 158 (1), 44-53 (2015) https://doi.org/10.1111/eea.12384

10. B.R. Blaauw, D. Polkb, A.L. Nielsen, Pest Manag Sci., 71(11), 1513-1522 (2015) https://doi.org/10.1002/ps.3955

11. M.L. Cornelius, C. Dieckhoff, K.A. Hoelmer, R.T. Olsen, D.C. Weber, M.V. Herlihy, E.J. Talamas, B.T. Vinyard, M.H. Greenstone, Biological Control, 103, 11-20. (2016) https://doi.org/10.1016/j.biocontrol.2016.07.011

12. C.R. Philips, T.P. Kuhar, G.P. Dively, G. Hamilton, J. Whalen, K. Kamminga, J. Econ. Entomol., 110(1), 192-200 (2017) https://doi.org/10.1093/jee/tow256

13. L.Maistrello, P. Dioli, M. Bariselli, G.L. Mazolli, I. Giacalone-Forini, Biol Invasions, 18, 3109-3116 (2016) https://doi.org/10.1007/s10530-016-1217-z 
14. K. Funayama, Appl. Entomol. Zool., 49, 265-268 (2005) https://doi.org/10.1303/jjaez.2005.265

15. A.L. Nielsen, G.C. Hamilton, J. Econ. Entomol., 102(3), 1133-1140 (2009) https://doi.org/10.1603/029.102.0335 